\title{
Forensic Accounting Education in the UAE
}

\author{
Dr. M. Ganga Bhavani ${ }^{1} \&$ Dr. Anupam Mehta ${ }^{2}$ \\ ${ }^{1}$ Assistant Professor, Manipal University, Academic City, Dubai, UAE \\ ${ }^{2}$ Associate Professor, Institute of Management Technology (IMT), Academic city, Dubai, UAE \\ Correspondence: Dr.M. Ganga Bhavani, Assistant Professor, Manipal University, Academic City, Dubai, UAE.
}

Received: November 14, 2017

Accepted: December 24, 2017

Online Published: January 4, 2018

doi:10.5430/afr.v7n1p214

URL: https://doi.org/10.5430/afr.v7n1p214

\begin{abstract}
This paper presents the current scenario of offerings and availability of forensic accounting education in universities in the UAE. This study is useful in gaining a complete understanding of available courses on forensic accounting at the graduate and postgraduate level, especially in accounting specialization. The results will help provide an insight into the direction of forensic accounting education in the UAE, where developing and improving forensic accounting education offerings has created serious buzz across the globe. Because of the increasing number of various corporate scandals all over the world, forensic accounting education has become the order of the day, and every accounting student needs to be trained in this field and every university has to offer it as part of the curriculum. The results of this study show that very few universities in the UAE offer and focus on this course as part of their curriculum in graduate and postgraduate levels. This study takes into consideration the current scenario of this course's offerings among UAE universities, and the second outcome of this paper provides a comparison of course contents with the recommendations of the National Institute of Justice (NIJ) in the USA.
\end{abstract}

Keywords: Forensic accounting, Course content, Graduate and postgraduate levels, Curriculum

\section{Introduction}

Recent corporate accounting scandals call into question the capabilities of financial auditors and accounting education. Traditional accounting graduates who become corporate accountants and internal and external auditors without proper understanding of fraud and forensic accounting are no longer in demand. The increasing number of white-collar crime frauds puts pressure on accounting educators, students, and professional organizations to venture into the specialized field of fraud and forensic accounting. This creates a need to raise awareness of fraud and forensic accounting education.

A gap between industry demand and university offerings exists, especially in accounting education in general and forensic accounting education in particular. Forensic accounting is defined as the use of accounting, auditing, and investigative skills to examine financial statements to be used in a court of law (Modugu \& Anyaduba, 2013). A forensic accountant can be hired to find fraud and settle disputes in corporations (Dreyer, 2014).

According to a document on forensic accounting education submitted by West Virginia University (Document No: 217589, dated March 2007), the demand for accounting students who have specialized qualifications in fraud and forensic accounting has grown significantly and is likely to continue to grow, creating an opportunity for colleges, universities, and other course developers to provide related courses and programs. The detection and prevention of fraud, especially financial fraud, using normal auditing procedures has become an incredibly difficult task not only to auditors but even to stakeholders (Cynthia, 2005). A very recent article by Bressler (2016) highlights the importance of special skills that must be acquired by auditors. Financial auditors must be trained in the areas of investigation and detection with various specialized forensic auditing techniques. Harris and Brown (2000) suggest that forensic accountants should have specialized skills on the rules of evidence and the law, analytical and investigative skills, excellent interpersonal communication skills, and so on. They pose questions on the capabilities of auditors and the methods they use to effectively and efficiently detect fraud in organizations.

Recognizing the fact that the demand for forensic accounting education has increased and accepting the importance of teaching this course at the university or college level, this article throws light on UAE universities and colleges. The remainder of this article is organized as follows: The next section provides an overview of literature on forensic accounting education in general and that in the Gulf region in particular. Then the need and significance of the study, 
objectives, research method, and results are discussed. Finally, the conclusion, limitations, and directions for future research are presented.

\section{Review of Literature}

Forensic accounting and fraud examination have continuously become a debated topic in the past few years, and many authors have studied big corporate scandals (Shaikh \& Talha, 2003). For over a decade now, accounting leaders such as Barry Melancon, the president and CEO of the American Institute of Certified Public Accountants, have called on accounting educators to provide students with "the knowledge and skills to understand the fundamental characteristics of fraud, identify factors that may indicate it exists, and acquire enhanced interviewing techniques" (Melancon, 2002). Accounting students are required to obtain knowledge of fraud and other forensic accounting services, along with regular accounting courses. Rezaee, Lo, Ha, and Suen (2016) state in their study that the present financial scandals, frauds, and related financial crises have driven more interest in forensic accounting and fraud examination practices. Business schools and accounting programs worldwide are incorporating ethical practices in their curriculums and paying attention to integrating forensic accounting into their accounting curriculums. In her study, Matson (2016) highlights that many opportunities in fraud auditing, forensic accounting, and fraud investigations exist. She also adds that just one course in forensic accounting is not enough to prepare students to become forensic accountants. Students need professional courses in forensic accounting as part of basic diploma courses as well as a master's degree. A study conducted by Smith and Crumbley (2009) found that in most of the universities are not differentiating the curriculum of forensic accounting and fraud examination. A study conducted by Seda and Peterson Kramer (2014) found that 95\% of their respondents believe that the demand for forensic accountants will increase in the foreseeable future. This emphasizes the importance of this kind of education in the world. Rezaee, Lander, and Reinstein (1996) have identified four universities that teach forensic accounting and discussed the contents of the course in detail. Seda and Peterson Kramer (2015) mention that very little research on international forensic accounting education exists. Koh, Arokiasam, and Suat (2009) discuss in their study that the increasing demand for forensic accounting is a recognized feature of most companies. Forensic accounting is rising as a discipline and covers fraud knowledge, financial expertise, and sound knowledge and understanding of business reality and the workings of the legal system (Bologna \& Lindquist, 1987). According to Dreyer (2014), forensic accounting is a relatively new concept. He adds that a forensic accountant usually learned through experience on the job, but now a number of colleges and business schools offer programs in this discipline. More programs are expected to open in the future.

There is a need to accept the fact that the universities have confusion on not only the course offerings but also content in the course. Some of the research studies helps to figure out the content. A study by Rezaee, Crumbley, and Elmore (2004) provides a direction to pick right content to serve the purpose of industry.

\subsection{In the Gulf Region}

Very little research literature is available in the area of forensic accounting in Gulf countries in general and in the UAE in particular. This is the first study on forensic accounting education in the UAE. A study on forensic accounting education conducted by Hidayat and Al-Hadrami gathered opinions from educators in universities in Bahrain. The results indicated that majority of the respondents are familiar with forensic accounting and expect an increase in demand for it in the future. However, the current scenario in universities in Bahrain is not remarkable. Another study on accounting practitioners conducted by Hidyat and Al-Sadiq (2014) in Bahrain reveals the importance of forensic accounting education in the kingdom and highlights data to incorporate in curriculums at the university level. Zadeh and Ramazani (2012) found the perception of forensic accounting among accountants in Iran. The outcome of this study reported that accountants in Iran are not aware of forensic accounting. Abdullah (2014) distributed a questionnaire to lecturers in Iraqi universities and found a significant positive relationship between forensic accounting education in universities and detection of financial frauds. Elitas, Karakoc, and Gorgulu (2011) conducted a study in Turkish universities to measure accounting instructors' awareness of the forensic accountancy profession. The authors learned from the instructors that the success of this course depends on proper training programs in higher education. In addition, they found that before forensic accounting education can be introduced in universities, seminars and workshops should be conducted to impart knowledge of this course and train the faculty, which in turn will satisfy the rationale for implementing this course at the university level.

\subsection{Need and Significance of Forensic Accounting Education in the UAE}

According to the results of KPMG's fraud survey in 2014, organizations are reporting more experiences of fraud than in prior years. In 2014, $75 \%$ of companies reported that they experienced an instance of fraud, an increase of $13 \%$ from data in 2003. Furthermore, Ernst \& Young's (2013) global survey pointed out that the main contributing factors 
of the prevalence of fraud are the growing complexity of organizations and systems, changes in business processes and activities, and so on. The UAE is not an exception to this. According to PWC's global economic crime survey (2014), $31 \%$ of the respondents in the UAE reported accounting fraud in their organizations, a figure that is significantly above Middle East's average of $22 \%$. The survey also revealed that asset misappropriation (78\%) is the most common economic crime in the UAE, followed by cybercrime, procurement fraud, and bribery and corruption.

With UAE moving on the path of faster development and transparency, there has been a greater need and requirement of the forensic accountants whose role is not only limited to the fraud but they also provide the litigation services in the UAE including the computation of any economic and financial loss incurred.

In the UAE Big four Accounting firms as well as many local accounting and auditing firms give extensive service on investigation and ligation support, creating a greater demand and need for the forensic accounting professionals in the UAE.

Litigation support helps in quantifying the economic loss and the damages related to the current litigation or pending litigation. In UAE companies Big four and many companies like Crowe Horwath, UHY, Axix Accoutning and Auditing, Xb4 provide extensive litigation support using the forensic accounting tools and techniques. The use of litigation support services and the extensive wasy companies provide these services makes it all the more case for providing the forensic accounting education in the UAE.

These deplorable results raise concerns about fraud investigation procedures in the UAE and highlight the importance and need for forensic accounting education as a stand-alone course in universities and business schools at the undergraduate, postgraduate, and other higher levels. The main objective of this study is to present the current scenario of forensic accounting education in universities in the UAE and to highlight the course curriculum followed by offering universities. This paper brings out to what extent the universities and colleges are equipping the managers with the knowledge and education on forensic accounting.

\subsection{About UAE}

The United Arab Emirates (UAE) is a geographically small country of 82,880 sq km consisting seven emirates with a capital of Abu Dhabi. Population, according to the National Bureau of Statistics estimates in 2010, reached to 8264 thousand people with $66 \%$ men and $33 \%$ women. The population tends to be relatively young and gender ratio is dominated by males. In many emirates the number of South Asians exceeds the local citizens. UAE is one of the major Centre for global oil production due to high availability of oil resources and low production cost. The annual economic report 2015 of UAE presents the per capita GDP is 3.9\% which shows increasing trend compared to previous years. The name of the currency in UAE is named as Arab Emirate Dhiram (AED), which is pegged with U.S.D \$1= AED 3.67 .

\subsection{System of Higher Education in the UAE}

Higher education in the UAE was founded in 1976 through its first university, United Arab Emirates University. The colleges and universities in the UAE, government supported and private alike, play an important role in the UAE's higher education system. The Ministry of Higher Education and Scientific Research (MOHESR) was established through 1992 Federal Law No. (4) With a view to overseeing higher education and scientific research policies in the UAE. The ministry is responsible for planning higher education and scientific research, licensing private institutions, preparing laws for the establishment of federal government institutions of higher education, accrediting foreign institutions, and so on. To ensure that colleges and universities in the UAE operate at international levels of quality, the Commission for Academic Accreditation (CAA) of the MOHESR was formed in 2000. The CAA runs a licensure program for institutions of higher education and regulates accreditation for each of their academic programs (source: Ministry of Higher Education and Scientific Research website, retrieved on September 25, 2016). The CAA's mission is to promote educational excellence across diverse institutions of higher learning in the UAE. The CAA developed its first Standards for Licensure and Accreditation in 2001, and the recent revision was made in 2007.

On December 12, 2011, the MOHESR established the Center for Higher Education Data and Statistics (CHEDS). The primary responsibility of CHEDS is to collect data from each higher education institution in the UAE. The purpose of this organization is to produce comprehensive reports on the UAE higher education sector through fact-based data on the performance of UAE higher education institutions. These reports are then used by the ministry and the CAA for strategic planning (source: Center for Higher Education Data and Statistics, November 2012 report). 
According to the report by CHEDS (2012), the UAE would have 102 higher education institutions (HEIs) by the end of October 2012. The UAE has different institutions, including private and state owned, for profit and not for profit, and institutions with different types of recognitions. Some institutions are solely based in the UAE, while others are branches of institutions from other countries. These higher education institutions can be divided into three categories: federal institutions, CAA licensed, and nonlicensed.

Federal institutions: Higher Colleges of Technology (HCT), UAE University, and Zayed University.

CAA-licensed institutions: By the end of 2011, there would be 74 licensed institutions per CHEDS. These licensed institutions include private and nonfederal entities regulated by the CAA.

Non-CAA-licensed free-zone branch campuses: These institutions are branch campuses of international institutions that offer instruction for degrees awarded by the home campus. They operate under emirate legislation, but without a federal license, within recognized free zones in Dubai and RAK.

\section{Research Method}

\subsection{Scope}

The scope of the data collection for this paper is limited only to federal and CAA-accredited universities in the UAE. Non-CAA-accredited universities are not included in this study. This paper covers various forensic accounting programs, including degrees, certificates, minors, and concentrations in forensic accounting in accounting or business universities and colleges.

This study is designed based only on secondary data. Data are collected from the websites of federal and CAA-accredited universities and colleges in the UAE. A total of 75 institutions accredited and licensed by the CAA are included in this study (retrieved from the MOHESR website on 4/10/16). Course description or content is collected from universities by writing personal mails to concerned university program directors or deans to request for a copy of the same.

The websites of all colleges and universities in the UAE were reviewed to determine the extent to which colleges and universities offer forensic accounting courses and to ascertain the educational models used (e.g., degrees in forensic accounting, minors, certificates, etc.). After a college or university website that contains information about forensic accounting education was identified, the website was searched for an online catalogue to get a description of the related courses and/or the curriculum's learning objectives and goals.

\section{Data and Analysis}

Table 1. UAE University Offerings on Forensic Accounting Education

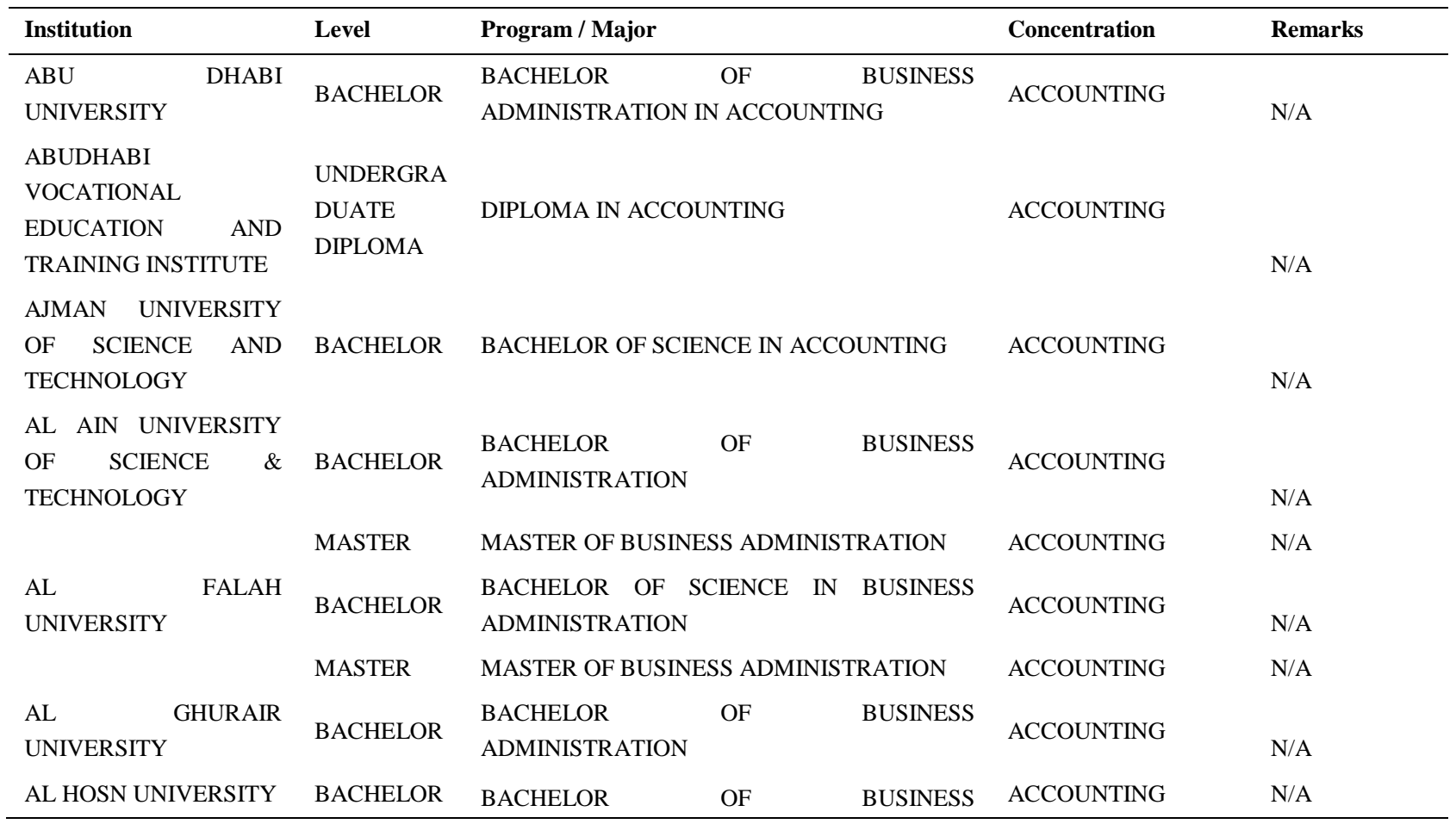


ADMINISTRATION IN ACCOUNTING

AL KHAWARIZMI INTERNATIONAL COLLEGE

AMERICAN

AMERICAN

UNIVERSITY IN THE

EMIRATES

AMERICAN

UNIVERSITY OF RAS

AL KHAIMAH
UNIVERSITY IN DUBAI
ASSOCIATE

BACHELOR

BACHELOR

BACHELOR

BACHELOR

AD

ASSOCIATE OF SCIENCE IN BUSINESS ADMINISTRATION

BACHELOR OF BUSINESS

ADMINISTRATION

BACHELOR OF

ADMINISTRATION

BACHELOR OF

ADMINISTRATION

BACHELOR

BACHELOR OF SCIENCE IN ACCOUNTING

BACHELOR OF SCIENCE IN BUSINESS

AMERICAN

UNIVERSITY

OF

SHARJAH
ADMINISTRATION - ACCOUNTING
MASTER OF SCIENCE IN ACCOUNTING

BACHELOR OF SCIENCE IN ACCOUNTING

BRITISH UNIVERSITY

IN DUBAI

CANADIAN

UNIVERSITY

DUBAI

CITY UNIVERSITY

COLLEGE OF AJMAN

EMIRATES CANADIAN

UNIVERSITY COLLEGE

EMIRATES COLLEGE

OF TECHNOLOGY

EMIRATES INSTITUTE

FOR BANKING AND

FINANCIAL STUDIES FINANCE
BACHELOR

AND FINANCE

$\begin{array}{lll}\text { BACHELOR OF BUSINESS } & \end{array}$

ADMINISTRATION

BACHELOR

BACHELOR

BACHELOR

BACHELOR OF

ADMINISTRATION

BACHELOR OF

ADMINISTRATION

BACHELOR OF FINANCIAL SCIENCES

BACHELOR OF SCIENCE IN BANKING AND FINANCE BUSINESS BUSINESS

BACHELOR
ACCOUNTING

ACCOUNTING

ACCOUNTING

ACCOUNTING AND FINANCE

FINANCE ACCOUNTING

ACCOUNTING

ACCOUNTING

ACCOUNTING

\begin{abstract}
HAMDAN BIN
MOHAMMED SMART

UNIVERSITY

INSTITUTE OF
\end{abstract}

MANAGEMENT
BACHELOR BACHELOR OF BUSINESS IN ACCOUNTING ACCOUNTING

BACHELOR
BACHELOR OF COMMERCE IN ACCOUNTANCY

N/A

N/A

N/A

N/A

N/A

downloand > Course description (https://www.au s.edu/info/2001 36/graduate_pro grams/503/mast er_of_science_i n_accounting/2 https://www.aus .edu/site/scripts/ google_results.p $\mathrm{hp} ? \mathrm{q}=$ Forensic + Accounting+

N/A

N/A

N/A

N/A

N/A

http://eibfs.ae/ei bfs.education/ac ademic-program s/bsc-in-banking -finance-account ing/

N/A

http://www.imtd ubai.ac.ae/progr am-structure-b-c 


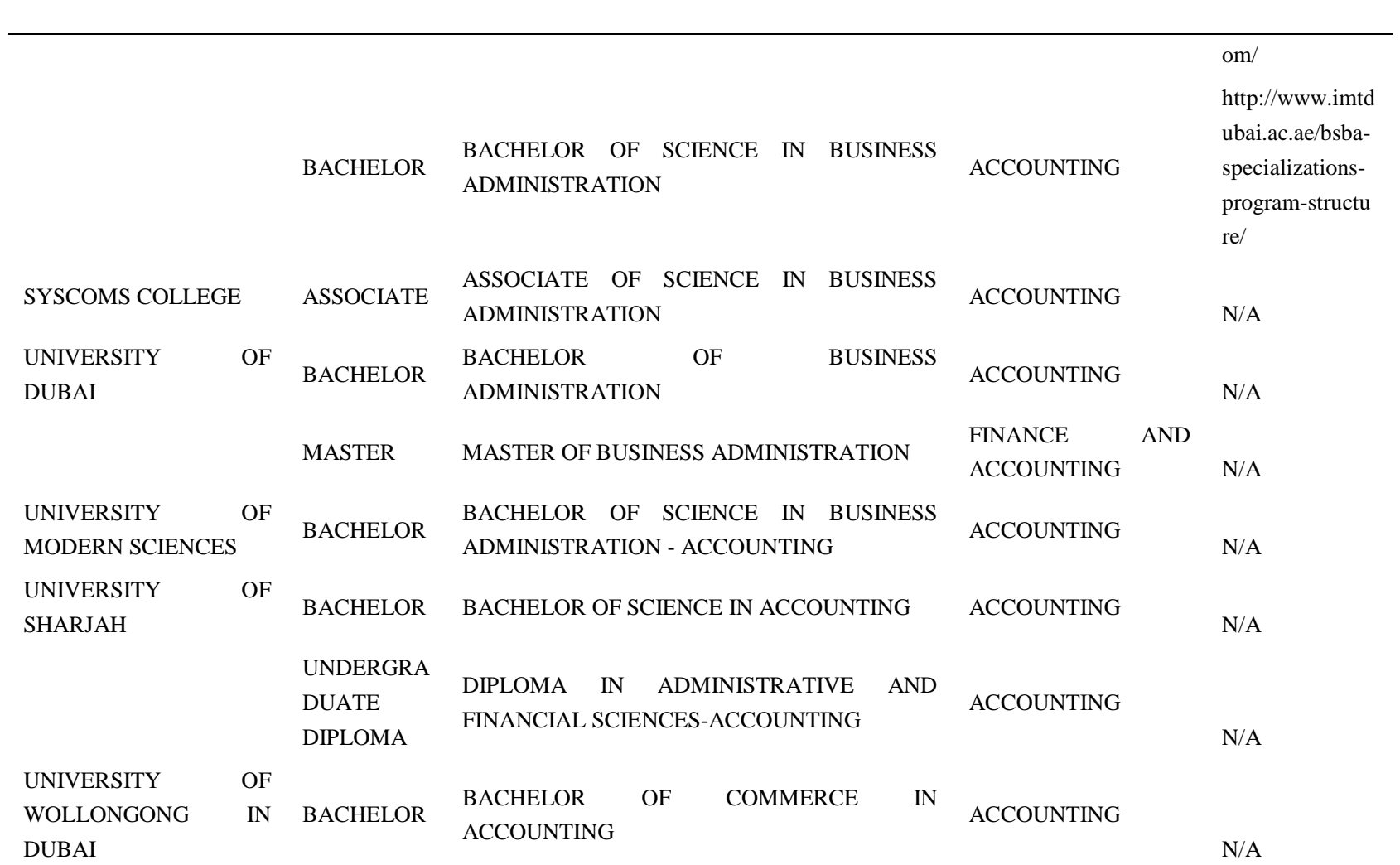

From the 75 licensed institutions, a total of 910 accredited programs were determined to be offered by universities (retrieved from MOHESR on 4/10/16). These programs include bachelor's degree, master's degree, and diploma certificate programs.

As shown in Table 1, 32 universities offer accounting specialization in bachelor's and master's degree programs in the UAE. Of the 32 universities, only 3 offer forensic accounting specialization in bachelor's and master's degree programs, which is equivalent to $9 \%(n=32)$. Out of a total of 910 approved programs in the UAE, only 5 programs in forensic accounting are available, which is equivalent to $0.005 \%(n=910)$. These deplorable results depict the current scenario of forensic accounting education in UAE universities. The universities that offer forensic accounting courses at the bachelor's degree level are Institute of Management Technology (IMT), American University of Sharjah (AUS), and Emirates Institute for Banking and Financial Services (EIBFS). In master's degree level, only American University of Sharjah offer forensic accounting courses.

This study has observed that no common content is being followed by the universities, and no consensus is set on how to uniformly integrate forensic accounting into the accounting curriculums of UAE universities. Currently, the universities offering forensic accounting (IMT, AUS, and EIBFS) follow their own course content. After copies of the course content from these universities were collected, this study has observed that only IMT has adopted a detailed content for this course, as compared with other universities (copies attached in the annexure). The American university also offers course content that is almost similar to that of IMT. What is common among these universities is that they look for principles of accounting or financial accounting as a prerequisite for their course. The course contents offered by these universities are almost similar. The contents for postgraduate courses offered by are more elaborate than those in undergraduate courses. It is also observed that these outlines carries a narrow definition of the forensic accountant as compared to a broad base education for Forensic accountant, that would enable the forensic accountant to provide a range of services including the identification, recording, settling extracting, sorting, verifying the past financial data to settle disputes. (Crumbley \& Smith, 2007)

According to a review of the websites that featured forensic accounting, as detailed in Table 1, the following educational course contents are being used by UAE universities, especially those that currently offer a forensic accounting course (IMT, AUS, and EIBFS). The course contents in forensic accounting (only the main headings) that are commonly offered by UAE universities are presented in Table 2 . 
Table 2. Sample Course Content of Forensic Accounting among UAE Universities

\begin{tabular}{|c|c|}
\hline Sessions & Content \\
\hline 1 & $\begin{array}{l}\text { Course Overview, Meaning scope of Forensic Accounting, concepts and techniques of Forensic } \\
\text { Accounting }\end{array}$ \\
\hline \multirow[t]{2}{*}{2,3} & Nature and Types of Fraud, Who Commits Fraud and Why? \\
\hline & $\begin{array}{l}\text { Definitions of fraud, General Usage, Specialized Usage, Legal Definitions, Types of Fraud } \\
\text { (Employee Embezzlement, Vendor Fraud, Customer Fraud, Management Fraud, Investment Scams } \\
\text { and Other Consumer Frauds) }\end{array}$ \\
\hline 4 & $\begin{array}{l}\text { Fraudulent Financial Statements, reasons why Financial Statements Fraud is committed:, Types of } \\
\text { Fraudulent Financial Statements, Revenue- and Inventory- Related Frauds, Liability, Asset \& } \\
\text { Inadequate Disclosure Frauds, Approaches to Fraud Detection }\end{array}$ \\
\hline 5 & $\begin{array}{l}\text { Uncovering "Creative" Accounting and Other "Red Flags" of Fraud, Finding out the areas of fraud. } \\
\text { Symptoms of fraud, Accounting anomalies, Internal control weaknesses }\end{array}$ \\
\hline 6,7 & $\begin{array}{l}\text { Approaches to Financial Fraud Investigation, Elements of a complete investigation , Tips and } \\
\text { techniques for more effective investigations, Practical investigative tools, - checklists, charts, mapping, } \\
\text { spreadsheets, How to prove suspected wrong doing, How to identify the perpetrator. }\end{array}$ \\
\hline 8 & $\begin{array}{l}\text { Applying Targeted Forensic Accounting Skills Fraud and CAATs. Benefits of CAATs. Fraud and } \\
\text { CAAT Issues. Need for Computer Tools. Sample Tools/CAATs. CAAT Methodology. }\end{array}$ \\
\hline 10 & $\begin{array}{l}\text { Evaluating your Company from a Forensic Audit Perspective, How to Detect and Minimise } \\
\text { Electronic Risk, Developing Audit Tests to Expose Eight Hard-to-Spot Fraud Practices }\end{array}$ \\
\hline $\begin{array}{ll}11 & 12\end{array}$ & $\begin{array}{l}\text { Anti Fraud program, case studies, what went wrong in all the case studies and lessons to be learnt from } \\
\text { these cases? }\end{array}$ \\
\hline \multirow[t]{2}{*}{13,14} & Fraud Prevention and Control. \\
\hline & $\begin{array}{l}\text { Introduction. Perception of Detection. Classic Approaches. Prevention Environment. Prevention } \\
\text { Measures. Accounting Cycles Approaches and Controls to Fraud Prevention }\end{array}$ \\
\hline 15 & $\begin{array}{l}\text { Legal Follow-Up-procedures and processes Forensic Accountant as an Expert Witness:-Introduction. } \\
\text { Role of a Forensic Accountant as a Witness in Court. Forensic Accountant as an Expert Witness. } \\
\text { Qualification and Admissibility of Accounting Evidence. Expert's Role in the Litigation Team. Pre } \\
\text { testimony Activities. Trial and Testimony }\end{array}$ \\
\hline
\end{tabular}

\section{Conclusion}

This is the first study on forensic accounting in the UAE's federal and CAA-accredited universities. This study found that very few universities are seriously concerned about a forensic accounting course and have incorporated it in their curriculums. As discussed, the fraud rate in the UAE is increasing, in the same manner that the job market for forensic accountants is increasing. Auditing firms, including the Big 4 companies, are searching for forensic accounting specialists. Auditors from the Financial Audit Department, the Dubai Police, and the Dubai Courts have signed an agreement with University of Wollongong in Dubai (UOWD) to study two subjects: introduction to forensic accounting and forensic and litigation framework (retrieved from the website of UOWD, news article released on February 25, 2009).

These facts prove that the market for forensic accountants and the demand for forensic accounting are growing. The UAE's federal and CAA-accredited universities should give some serious thought to bringing this course into their undergraduate and postgraduate curriculums to train accounting and auditing students. There is a need to offer at least one forensic accounting course across universities in the UAE. The second result of this study shows a very strong and positive match between UAE universities' forensic accounting course content and the NIJ model curriculum. IMT's and AUS's contents are very elaborate with a vast coverage. This study is limited to federal and CAA-accredited universities in the UAE. Future research can be extended to include non-CAA-accredited universities across GCC nations. 


\section{References}

"Forensic accounting \& litigation support | UHY International. (2017). Forensic accounting \& litigation support | UHY International. (2017). Uhy.com. Retrieved 9 July 2017, from http://www.uhy.com/services/corporate-services/forensic-accounting-litigation-support/

Abdullah T. T., Alfadhl, M.M., Yahya S., \& Rabi A.M. (2014). The Role of Forensic Accounting in Reducing Financial Corruption: A Study in Iraq. International Journal of Business and Management, 9(1), 26-34.

Adrain Nicholwa Koh, Lawrence Arokiasamy \& Cristal Lee ah Suat. (2009). Forensic Accounting: Public Acceptance towards Occurrence of Fraud Detection. International Journal of Business and Management, 4(11).

Association of Certified Fraud Examiners (ACFE). (2014). Report to the Nations on Occupational Fraud and Abuse: 2014 Global Fraud Study. Available at: http://www.acfe.com/rttn.aspx.

Association of Certified Fraud Examiners. (1996). Report to the nation on occupational fraud and abuse. Austin, TX: ACFE.

Bologna, G .J. \& Lindquit R.J. (1987). Fraud Auditing and Forensic Accounting New Tolls and Techniques. Hoboken, New Jervey: Wiley Publications.

Centre for Higher Education Data and Statistics CHEDS UAE. Accessed through, www.cheds.ae

Crumbley, D., \& Smith, G. (2007). A broad based approach to forensic accounting is needed. The Value Examiner, 13-19.

Cynthia, H. (2005). Analysis ratios for detecting Financial Statement fraud. ACFE Fraud Magazine.

Davis, C., R Farrell and S. Ogilby. (2009). Characteristics and skills of the forensic accountant. American Institute of Certified Public Accountants (AICPA).

Diane Matson. (2016). Independent Studies in Forensic Accounting: Some Practical Ideas. Journal of Forensic \& Investigative Accounting, 8(2), Special Issue.

Dubai, UAE Accounting Firm | Litigation Support Page | XB4 Solutions. (2017). Xb4.com. Retrieved 9 July 2017, from http://xb4.com/litigation_support.php

Dubai, UAE Accounting Firm | Litigation Support Page | XB4 Solutions. (2017). Xb4.com. Retrieved 9 July 2017, from http://xb4.com/litigation_support.php

Elitas, C, Karakoc M., \& Gorgulu. (2011). Forensic Accounting and Financial Fraud in Nigeria: An Empirical Approach. International Journal of Business and Social Science, 4(7), 281-289.

Ernst \& Young's Global Survey. (2013). Accessed through, www.ey.com/Publication/...Global-Fraud-Survey/.../EY-13th-Global-Fraud-Survey

Forensic Accounting and Litigation Support | Crowe Horwath Mongolia LLC. (2017). Crowehorwath.net. Retrieved 9 July 2017, from http://www.crowehorwath.net/MN/services/audit/Forensic_Accounting_and_Litigation_Support.aspx

Harris, C.K. \& A.M. Brown. (2000). The qualities of a forensic accountant. Pennsylvania CPA Journal, 71(1), 6-8.

Hidayat S. E., Al-Sadiq A.A. (2014). A Survey on the Need to Offer Forensic Accounting Education in the Kingdom of Bahrain International.

Junaid M. Shaikh \& Mohammad Talha. (2003). Credibility and expectation gap in reporting on uncertainities. Managerial Auditing Journal, 18/6/7, 517-529. https://doi.org/10.1108/02686900310482650

KPMG Singapore Fraud Survey. (2014). in support of Singapore Management University, accessed through www.kpmg.com/SG/.../Advisory-Forensic-Singapore-Fraud-Survey-2014

Linda Bressler. (2016). The role of forensic accountants in fraud investigations: Importance of attorney and judge's perceptions. Journal of Finance and Accountancy.

Melancon, B. C. (2002). A new accounting culture. Journal of Accountancy, (October), 27 - 30

Ministry Of Higher Education \& Scientific Research in UAE. Accessed through www.mohesr.gov.aelen

Modugu K. P. \& Anyaduba, J. O. (2013). Forensic Accounting and Financial Fraud in Nigeria: An Empirical Approach. International Journal of Business and Social Science, 4(7), 281-289.

Price Water Coopers. (PWC, 2014). Economic Crime in the UAE, accessed through www.pwc.com/me. 
Rezaee, Z., Lander, G. H., \& Reinstein, A. (1996). Integrating forensic accounting into the accounting curriculum. Accounting Education: A Journal of Theory, Practice and Research, 1, 147 - 162.

Rezaee, Zabihollah, Crumbley, D. Larry, \& Elmore, Roger C. (2004). Forensic Accounting Education: A Survey of Academicians and Practitioners. Advances in Accounting Education, 6, 193231.

Seda, M. \& Kramer, B. (2014). An examination of the availability and composition of forensic accounting education in the United States and other countries. Journal of Forensic \& Investigative Accounting, 6(1), 1 - 46.

Seda, Mike, \& Peterson Kramer, Bonita K. (2014). An Examination of the Availability and Composition of Forensic Accounting Education in the United States and Other Counties. Journal of Forensic \& Investigative Accounting, (January-June 2014), 6, 1-46.

Seda, Mike, \& Peterson Kramer, Bonita K. (2015). A Comparison of U.S. Forensic Accounting Programs with the National Institute of Justice Funded Model Curriculum. Journal of Forensic \& Investigative Accounting, 7(2), July - December 2015.

Services. (2017). Axisauditing.com. Retrieved 9 July 2017, from http://www.axisauditing.com/services/

Smith, G. S., \& Crumbley, D. L. (2009). How divergent are pedagogical views towards fraud/forensic accounting curriculum? Global Perspectives on Accounting Education, 6, 1-24.

Sutan Emir Hidayat1 , Abdullah Hamzah Al-Hadrami. (2015). Forensic Accounting Education In Bahrain: A Survey on Educators' Opinion. Forensic Accounting Education In Bahrain: A Survey on Educators' Opinion. Int. J. Ped. Inn. 3, No. 1.

University of Wollongong in Dubai. Accessed through www.uowdubai.ac.ae

West Virginia University. (March 2007). Education and Training in Fraud and Forensic Accounting: A Guide for Educational Institutions, Stakeholder Organizations, Faculty, and Students. Document No.: 217589, Award Number: 2001-RC-CX-K003.

Zabihollah Rezaee, Daniel Lo, Michael Ha \& Alexis Suen. (2016). Forensic Accounting Education and Practice: Insights From China. Journal of Forensic \& Investigative Accounting, 8(1), January-June.

Zadeh, H.E \& Ramazani, M. (2012). Accountant's Perception of Forensic Accounting (Case Study of Iran). Global Journal of Management and Business Research, 12(6), 1-4. 